\title{
ANALISIS HUBUNGAN BEBAN KERJA DENGAN KONDISI PSIKOLOGIS PERAWAT RELAWAN COVID-19
}

\section{Firda Apriyanti, Yati Afiyanti, Syamsul Firdaus}

Universitas Muhammadiyah Banjarmasin, Universitas Indonesia (UI) Depok Jawa Barat, Poltekkes Kemenkes Banjarmasin, Indonesia

Email: firdaapriyanti111@gmail.com, syamsulfirdaus1966@gmail.com, yatiafiyanti@yahoo.com

\begin{abstract}
Abstrak
Perawat relawan merupakan garda terdepan dalam melakukan perawatan COVID19. Mereka memiliki risiko lebih besar terpapar karena sering berinteraksi dengan pasien yang dicurigai atau positif COVID-19. Kondisi psikologis adalah kondisi mental yang bisa memengaruhi kehidupan sehari-hari seorang individu perawat relawan COVID-19. Jika kondisi psikologis seseorang terganggu maka akan berpengaruh pada kehidupannya, tidak hanya dapat merusak interaksi atau hubungan dengan orang lain, namun juga dapat menurunkan produktivitas kerja perawat tersebut. Kondisi psikologis perawat relawan erat kaitannya dengan beban kerja perawat relawan itu sendiri karena beban kerja yang terlalu banyak dapat menyebabkan ketegangan dalam diri seseorang sehingga menimbulkan stres, kecemasan hingga dapat mengakibatkan depresi dan dapat memengaruhi perannya sebagai perawat relawan COVID-19. Penelitian ini bertujuan untuk menganalisis hubungan beban kerja dengan kondisi psikologis perawat relawan COVID-19. Metode pada penelitian ini menggunakan desain analitik kuantitatif dengan pendekatan cross sectional. Jumlah sampel dalam penelitian ini yaitu 200 orang perawat relawan COVID-19 berdasarkan teknik sampling yang mengacu pada teori Maxwell (1999). Tempat penelitian ini dilakukan di seluruh Indonesia. Analisis data menggunakan uji Chi-square, instrumen yang digunakan adalah kuesioner dalam bentuk Google Form. Hasil penelitian ini menunjukkan bahwa terdapat hubungan antara beban kerja terhadap kondisi psikologis depresi, cemas dan stres perawat relawan COVID-19.
\end{abstract}

Kata Kunci: COVID-19; Beban Kerja; Kondisi Psikologis, Perawat Relawan

\section{Abstract}

Volunteer nurses are the frontline in performing COVID-19 treatment. They have a higher risk of exposure because they often interact with patients suspected or positive of COVID-19. The psychological condition is a mental condition that can influence the daily life of an individual COVID-19 volunteer nurses. If the psychological condition of individuals is hampered, it will influence their life, not only can ruin interactions or relationships with others but also decrease the work productivity of the nurse. The psychological condition of volunteer nurses is closely related to the workload of volunteer nurses because too much workload can cause tension in a person, causing stress, anxiety and depression and it can influence their role as COVID-19 volunteer nurses. This study aims to analyze the

$\begin{array}{ll}\text { How to cite: } & \text { Apriyanti, F., Afiyanti, Y., Firdaus, S., (2022) Analisis Hubungan Beban Kerja dengan Kondisi Psikologis } \\ & \text { Perawat Relawan Covid-19, Syntax Idea, 4(1), https://doi.org/10.36418/syntax-idea.v4i1.1734 } \\ \text { E-ISSN: } & \text { 2684-883X } \\ \text { Published by: } & \text { Ridwan Institute }\end{array}$


relationship between workload with the psychological conditions of COVID-19 volunteer nurses. The method in this study used a quantitative analysis design with a cross-sectional approach. The number of samples in this study was 200 COVID19 volunteer nurses according to sampling technique referring to Maxwell theory (1999). This research was conducted throughout Indonesia. Data analysis used the Chi-square test. The instrument used was a questionnaire in the form of Google Form. The results of the study showed that there was a relationship between workload and psychological conditions of depression, anxiety, and stress on COVID-19 volunteer nurses.

Keywords: COVID-19; Psychological Condition; Workload; Volunteer Nurse

\section{Received: 2021-12-22; Accepted: 2022-01-05; Published: 2022-01-20}

\section{Pendahuluan}

Dunia saat ini sedang mengalami perubahan kondisi begitu besar akibat adanya bencana COVID-19. COVID-19 merupakan wabah pandemi virus berasal dari Wuhan yang dapat menyerang saluran pernafasan hingga mengakibatkan kematian. Di Indonesia kondisi ini sangat membutuhkan perhatian dari semua lapisan masyarakat baik dalam upaya pencegahan maupun penanganannya salah satunya yaitu menjadi relawan bencana. Wabah pandemi COVID-19 sudah merebak di Indonesia pada awal tahun 2020, pemerintah dan tenaga medis mulai kewalahan menangani pasien yang membludak datang ke rumah sakit. Pemerintah akhirnya memanggil tenaga kesehatan di Indonesia untuk menjadi relawan penanganan pandemi COVID-19 di rumah sakit rujukan yang kekurangan sumber daya. Relawan perawat merupakan salah satu tenaga kesehatan garda terdepan (frontline) dalam melakukan perawatan COVID-19. Perawat yang bekerja di ruang tersebut memiliki risiko yang lebih besar untuk berinteraksi dengan pasien atau penderita yang dicurigai positif COVID-19. Hal tersebut dapat berpengaruh terhadap kesehatan mental mereka (Santoso, dkk., 2020). Menghadapi situasi kritis ini, petugas kesehatan di garis depan yang terlibat langsung pada diagnosis, pengobatan, dan perawatan pasien COVID-19 berisiko terpengaruh secara psikologis dan gejala kesehatan mental lainnya.

Beban kerja yang terlalu banyak dapat menyebabkan ketegangan dalam diri seseorang sehingga menimbulkan stres. Hal ini bisa disebabkan oleh tingkat keahlian yang dituntut terlalu tinggi, kecepatan kerja yang juga terlalu tinggi, volume kerja yang terlalu banyak dan sebagainya. Kecemasan akibat beban kerja juga banyak terjadi hingga dapat mengakibatkan depresi. Hal ini sejalan dengan pendapat dari (Rosyanti \& Hadi, 2020), perawat mengalami kesulitan mempertahankan kondisi kesehatan fisik dan mental yang berisiko mengalami gangguan psikologis seperti depresi, kecemasan, stres berat, dan kelelahan. Faktor risiko lain yang diidentifikasi adalah perasaan tidak didukung, kekhawatiran tentang kesehatan pribadi, takut membawa infeksi dan menularkannya kepada anggota keluarga atau orang lain, diisolasi, perasaan tidak pasti, stigmatisasi sosial, beban kerja yang berlebihan, dan merasa tidak aman ketika memberikan layanan perawatan dan kesehatan pada pasien COVID-19. 
Berdasarkan studi sebelumnya mengenai gambaran faktor yang mempengaruhi kondisi psikologis perawat pada masa pandemi COVID-19 ditemukan bahwa kondisi psikologis yang dialami oleh perawat diantaranya sebanyak 39,1\% mengalami gangguan psikologis yaitu stres, kecemasan dan depresi (Sabir, Arafat, \& Yusuf, 2021). Stres dan kecemasan adalah reaksi terhadap situasi yang mengancam dan tak terduga seperti dalam wabah pandemi COVID-19. Reaksi terkait stres meliputi perubahan konsentrasi, lekas marah, cemas, susah tidur, berkurangnya produktivitas, dan konflik antarpribadi, dalam kasus selanjutnya, mereka akan mengalami kondisi kejiwaan yang lebih parah, pemisahan dari keluarga, situasi abnormal, peningkatan paparan, ketakutan akan penularan COVID-19, perasaan gagal dalam menangani prognosis yang buruk, fasilitas teknis yang tidak memadai untuk membantu merawat pasien (Rosyanti \& Hadi, 2020).

Di Kalimantan dalam hal ini di kota Pontianak menurut penelitian sebagian besar tenaga kesehatan mengalami gangguan psikologis yang meliputi kecemasan, depresi, dan insomnia selama pandemi COVID-19 (57,6\%; 52,1\%; dan 47,9\%). Perawat relawan yang bekerja menangani pasien positif COVID-19 cenderung lebih tinggi mengalami kecemasasan, depresi, dan insomnia dibandingkan dengan yang tidak. Persepsi perawat yang merasa berisiko terpapar COVID-19 signifikan berhubungan dengan masalah psikologis seperti gangguan kecemasan, depresi, dan insomnia. (Hanggoro, 2020). Kondisi psikologis adalah kondisi mental yang bisa memengaruhi kehidupan sehari-hari seorang individu. Berdasarkan uraian tersebut penelitian ini menganalisis tentang hubungan beban kerja dengan kondisi psikologis yang meliputi stres, cemas dan depresi pada perawat relawan COVID-19.

\section{Metode Penelitian}

Jenis penelitian ini merupakan penelitian analitik dengan pendekatan kuantitatif, menggunakan desain penelitian analisis deskriptif dengan pendekatan cross sectional. Populasi dalam penelitian ini adalah seluruh perawat relawan COVID-19 di Indonesia. Sampel dalam penelitian ini adalah perawat relawan COVID-19 di seluruh Indonesia berjumlah 200 orang responden. Teknik sampling mengacu pada studi oleh (Setyowati, Chung, Yusuf, \& Haksama, 2020) yang menyarankan ukuran sampel minimum adalah 200 responden untuk memproduksi statistik yang memadai dalam penelitian kuantitatif. Penelitian ini dilakukan di Indonesia dengan membagikan kuesioner secara online menggunakan aplikasi Google Form. Pengumpulan data dilakukan dari 01 Oktober-31 Oktober 2021. Instrumen yang digunakan dalam penelitian ini adalah kuesioner beban kerja perawat relawan COVID-19, dan kuesioner untuk mengukur tingkat stres, cemas dan depresi dengan menggunakan DASS 42.

Peneliti mengumpulkan data salah satunya dengan cara masuk ke dalam grup aplikasi chatting whatsapp relawan COVID-19. Peneliti memberikan kuesioner dengan mengirimkan link melalui media jejaring online seperti; whatsapp, e-mail dan jejaring online lainnya dalam bentuk aplikasi Google Form terhadap perawat relawan COVID19 di Indonesia. Responden diminta untuk mengisi informed consent secara online 
sebelum mengisi kuesioner sebagai bentuk persetujuan mengikuti penelitian. Data yang telah terkumpul kemudian ditabulasi ke dalam matriks pengumpulan data yang telah dibuat sebelumnya oleh peneliti dan kemudian dilakukan analisis data. Untuk menganalisis hubungan beban kerja dengan kondisi psikologis perawat relawan COVID-19 digunakan uji statistik dengan uji korelasi Chi-square.

\section{Hasil dan Pembahasan}

\section{A. Hasil Penelitian}

\section{Analisis Univariat}

1) Karakteristik Individu Perawat Relawan COVID-19

Tabel 1

Distribusi Frekuensi Karakteristik Individu Perawat Relawan COVID-19

\begin{tabular}{|c|c|c|c|c|}
\hline No & \multicolumn{2}{|c|}{$\begin{array}{c}\text { Kategori Karakteristik Individu Perawat } \\
\text { Relawan COVID-19 }\end{array}$} & $\begin{array}{l}\text { Frekuensi } \\
\text { (Orang) }\end{array}$ & $\begin{array}{c}\text { Persentase } \\
(\%)\end{array}$ \\
\hline \multirow[t]{3}{*}{1.} & \multirow[t]{2}{*}{ Usia } & $\begin{array}{l}\text { Dewasa Awal } \\
(18-35 \text { tahun })\end{array}$ & 166 & $83 \%$ \\
\hline & & $\begin{array}{l}\text { Dewasa Madya } \\
\text { (36-60 tahun) }\end{array}$ & 34 & $17 \%$ \\
\hline & \multicolumn{2}{|l|}{ Total } & 200 & $100 \%$ \\
\hline \multirow[t]{3}{*}{2.} & \multirow[t]{2}{*}{ Jenis Kelamin } & Laki-laki & 103 & $51,5 \%$ \\
\hline & & Perempuan & 97 & $48,5 \%$ \\
\hline & \multicolumn{2}{|l|}{ Total } & 200 & $100 \%$ \\
\hline \multirow[t]{3}{*}{3.} & \multirow[t]{2}{*}{ Pendidikan Terakhir } & Vokasi (D3, D4) & 83 & $41,5 \%$ \\
\hline & & Profesi (S1, Ners) & 117 & $58,5 \%$ \\
\hline & Total & & 200 & $100 \%$ \\
\hline \multirow[t]{3}{*}{4.} & \multirow[t]{2}{*}{ Status Perkawinan } & Belum Menikah & 64 & $32 \%$ \\
\hline & & Sudah Menikah & 136 & $68 \%$ \\
\hline & Total & & 200 & $100 \%$ \\
\hline \multirow[t]{3}{*}{5.} & \multirow[t]{2}{*}{ Penyakit Bawaan } & Ada & 59 & $29,5 \%$ \\
\hline & & Tidak Ada & 141 & $70,5 \%$ \\
\hline & Total & & 200 & $100 \%$ \\
\hline
\end{tabular}

Sumber: Data Primer, 2021

2) Beban Kerja Perawat Relawan COVID-19

Tabel 2

Distribusi Frekuensi Beban Kerja Perawat Relawan COVID-19

\begin{tabular}{cccc}
\hline No & $\begin{array}{c}\text { Kategori Beban Kerja Perawat Relawan } \\
\text { COVID-19 }\end{array}$ & $\begin{array}{c}\text { Frekuensi } \\
\text { (Orang) }\end{array}$ & Persentase (\%) \\
\hline 1. & Beban Kerja Berat & 112 & $56 \%$ \\
\hline 2. & Beban Kerja Sedang & 80 & $40 \%$ \\
\hline 3. & Beban Kerja Ringan & 8 & $4 \%$ \\
\hline & Total & $\mathbf{2 0 0}$ & $\mathbf{1 0 0 \%}$ \\
\hline
\end{tabular}

Sumber: Data Primer, 2021 


\section{3) Kondisi Psikologis Perawat Relawan COVID-19}

\section{Tabel 3}

Distribusi Frekuensi Kondisi Psikologis Perawat Relawan COVID-19

\begin{tabular}{|c|c|c|c|c|}
\hline \multirow{3}{*}{$\begin{array}{l}\text { No } \\
1 .\end{array}$} & \multicolumn{2}{|c|}{$\begin{array}{l}\text { Kategori Kondisi Psikologis Perawat Relawan } \\
\text { COVID-19 }\end{array}$} & \multirow{2}{*}{$\begin{array}{c}\begin{array}{c}\text { Frekuensi } \\
\text { (Orang) }\end{array} \\
57 \\
\end{array}$} & \multirow{2}{*}{$\begin{array}{c}\text { Persentase (\%) } \\
28,5 \% \\
\end{array}$} \\
\hline & Depresi & Berat & & \\
\hline & & Sangat Berat & 143 & $71,5 \%$ \\
\hline & Total & & 200 & $100 \%$ \\
\hline \multirow[t]{3}{*}{2.} & Cemas & Berat & 10 & $5 \%$ \\
\hline & & Sangat Berat & 190 & $95 \%$ \\
\hline & Total & & 200 & $100 \%$ \\
\hline \multirow[t]{4}{*}{3.} & Stres & Sedang & 22 & $11 \%$ \\
\hline & & Berat & 64 & $32 \%$ \\
\hline & & Sangat Berat & 114 & $57 \%$ \\
\hline & Total & & 200 & $100 \%$ \\
\hline
\end{tabular}

4) Analisis Bivariat

Sumber: Data Primer, 2021

Hubungan antara Beban Kerja dengan Kondisi Psikologis Perawat Relawan COVID-19

\section{Tabel 4}

Hasil Pengujian Hubungan antara Beban Kerja dengan Kondisi Psikologis Kondisi Psikologis

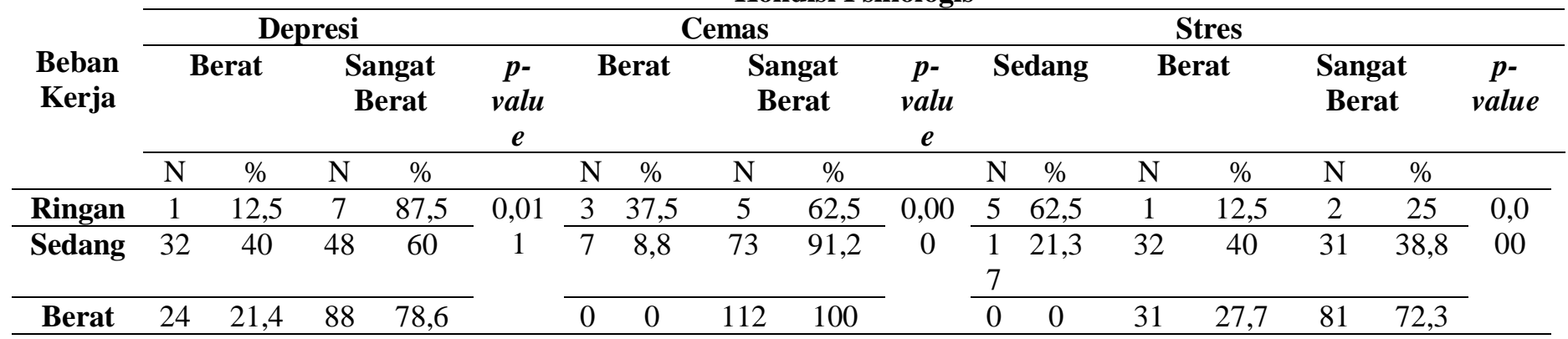

Sumber: Data Primer, 2021

\section{B. Pembahasan}

1. Analisis Univariat

a. Karakteristik Individu Perawat Relawan COVID-19 di Indonesia

Subjek dalam penelitian ini adalah perawat relawan COVID-19 di Indonesia. Dilihat dari usia, sebagian besar responden berada pada usia dewasa awal (18-35 tahun) sebanyak 166 orang (83\%). Seperti yang diungkapkan oleh (Putri, 2019) bahwa tahap dewasa awal yaitu antara usia 18 tahun sampai 35 tahun. Pada tahap ini manusia mulai menerima dan memikul tanggung jawab yang lebih berat. Mereka memiliki daya tahan dan taraf kesehatan yang prima sehingga dalam melakukan berbagai kegiatan tampak inisiatif, kreatif, energik, cepat, dan proaktif. Masa dewasa awal merupakan masa yang penuh dengan masa ketegangan emosional, ketegangan emosional seringkali ditempatkan dalam ketakutan atau kekhawatiran. Ketakutan atau kekhawatiran yang timbul 
ini pada umumnya bergantung pada tercapainya penyesuaian terhadap persoalan yang dihadapi pada saat tertentu atau sejauh mana sukses atau kegagalan yang dialami dalam penyelesaian persoalan. Karakteristik usia lebih didominasi oleh usia dewasa awal karena orang-orang pada usia dewasa awal cenderung memiliki semangat lebih dalam mencari nafkah sehingga tidak terlalu memperhatikan resiko yang akan didapatkannya.

Dari jenis kelamin, sebagian besar responden berjenis kelamin laki-laki sebanyak 103 orang $(51,5 \%)$. Dalam penelitian ini penyebab perawat relawan COVID-19 didominasi oleh laki-laki karena laki-laki lebih memiliki keberanian menghadapi tantangan dan bekerja jauh dari keluarga dibanding perempuan. Laki-laki dalam masa mencari pekerjaan lebih berani mengambil resiko. Namun jika dilihat dari jumlah persentase karakteristik jenis kelamin responden terlihat cukup seimbang antara laki-laki dan perempuan. Hal ini berarti bahwa keinginan seseorang untuk menjadi perawat relawan COVID-19 tidak dipengaruhi oleh jenis kelaminnya.

Dari pendidikan terakhir, sebagian besar pendidikan terakhir responden adalah profesi sebanyak 117 orang (58,5\%). Menurut relevansi pendidikan terakhir perawat pada era sekarang adalah pendidikan profesi karena profesi lebih direkomendasikan oleh pemerintah dibanding pendidikan vokasi. Jumlah lulusan profesi semakin tahun juga semakin bertambah. Sejalan dengan pendapat dari (Yunere \& Yaslina, 2020) menyatakan bahwa tingkat pendidikan yang lebih tinggi pada umumnya menyebabkan seseorang lebih mampu dan bersedia menerima posisi dan tanggung jawabnya. Pada kenyataannya semakin waktu berjalan maka seseorang akan mencari atau mengikuti strata pendidikan yang lebih tinggi dari sebelumnya dengan melihat prospek kerja yang semakin tahun akan mencari perawat yang stratanya lebih tinggi.

Berdasarkan status perkawinan responden sebagian besar berada pada status sudah menikah yaitu sebanyak 136 orang (68\%). Dalam penelitian yang didapatkan alasan perawat relawan COVID-19 didominasi oleh yang berstatus sudah menikah karena perawat relawan banyak yang masih muda dan freshgraduate dan masih mencari pengalaman kerja. Perawat yang sudah menikah memutuskan menjadi perawat relawan COVID-19 salah satunya karena kebutuhan ekonomi yang menuntutnya untuk mendapatkan uang tambahan karena insentif yang didapatkan relawan cukup besar dibanding gaji perawat biasa.

Sedangkan berdasarkan penyakit bawaan, sebagian besar responden tidak ada penyakit bawaan yaitu sebanyak 141 orang (70,5\%), karena perawat relawan yang memiliki penyakit bawaan tertentu lebih rentan mengalami penularan COVID-19 sehingga mereka yang memiliki penyakit bawaan cenderung akan lebih takut menjadi perawat relawan COVID-19 dibanding yang tidak memiliki penyakit bawaan. Hal ini didukung oleh Kepala Lembaga Biologi Molekuler Eijkman Amin Soebandrio yang berpendapat bahwa 
penyakit penyerta dapat membuat sistem imun seseorang menjadi kurang baik. Hal itu menyebabkan mereka mudah menderita komplikasi penyakit. (Wijaya dalam BBC News Indonesia, 2020). Dari penelitian ini disimpulkan bahwa seseorang yang memiliki penyakit bawaan cenderung menghindari menjadi perawat relawan COVID-19 karena merasa takut akan penularan virus tersebut yang akan membawa dampak buruk terhadap dirinya.

b. Beban Kerja Perawat Relawan COVID-19 di Indonesia

Berdasarkan hasil penelitian menunjukkan bahwa responden yang memiliki beban kerja berat sebanyak 112 orang (56\%). (Sonia Amelia Pratiwi Tarigan, 2021) menyatakan bahwa salah satu faktor yang mempengaruhi beban kerja perawat adalah perbandingan antara jumlah perawat dengan jumlah pasien yang harus ditangani, hal ini berkaitan dengan hasil penelitian ini responden menjawab dalam pertanyaan yang ada di dalam kuesioner bahwa responden merasa tidak seimbangnya tenaga perawat dibanding dengan pasien COVID-19. Dalam hal ini berarti jumlah pasien COVID-19 yang harus dilakukan perawatan akan berpengaruh terhadap beban kerja perawat relawan itu sendiri. Faktor lain yang mempengaruhi beban kerja perawat relawan yaitu kegiatan pokok yang dilakukan perawat relawan COVID-19 sedikit berbeda dengan kegiatan pokok perawat biasa seperti adanya kegiatan tambahan dan waktu yang dibutuhkan dalam melaksanakan perawatan juga berbeda seperti harus memonitor pasien lebih ketat lagi dalam masa perawatan. Dalam penelitian ini beban kerja yang berlebihan sangat berpengaruh terhadap produktifitas tenaga kesehatan, terutama tenaga perawat relawan COVID-19 dalam melakukan perawatan kepada pasien COVID-19. Beban kerja juga dapat mempengaruhi mental seseorang, jika beban kerjanya berat maka akan lebih cenderung dapat menyebabkan mental atau kondisi psikologis seseorang terganggu.

c. Kondisi Psikologis Perawat Relawan COVID-19 di Indonesia

Berdasarkan hasil penelitian menunjukkan bahwa responden yang memiliki depresi sangat berat sebanyak 143 orang $(71,5 \%)$, cemas sangat berat sebanyak 190 orang (95\%), dan stres sangat berat sebanyak 114 orang (57\%). Ini berarti bahwa perawat relawan COVID-19 di Indonesia mayoritas memiliki depresi, cemas dan stres yang berat karena tekanan dalam pekerjaan yang mengharuskan merawat pasien COVID-19 dimana COVID-19 ini adalah penyakit menular baru yang menyebar di seluruh dunia. Hal ini sesuai dengan penelitian ini dimana dapat dilihat dari persebaran pernyataan dalam kuesioner bahwa sebagian besar responden menjawab bahwa perasaan stres dan cemas mereka sangat meningkat sehingga sampai menyebabkan depresi ketika mereka harus merawat pasien COVID-19 karena salah satu alasannya yaitu takut tertular ataupun menularkan kepada keluarga yang ada di rumah.

Stres merupakan ketidakseimbangan untuk menyesuaikan diri dengan tuntutan lingkungan. Ketidakmampuan untuk beradaptasi dengan baik terhadap 
kondisi sekitar (stresor) dapat menjadi pencetus berbagai gangguan baik biologis, psikologis, sosial dan spiritual. Pada dasarnya stresor yang timbul tidak dapat membahayakan kehidupan. Stresor tidak selalu bersifat buruk. Stresor diperlukan untuk meningkatkan kematangan individu, kewaspadaan, dan kompetisi dalam kehidupan sehari-hari. Kecemasan merupakan rasa tidak nyaman, atau kekhawatiran akan sesuatu hal yang tidak menyenangkan. Kecemasan yang berlebihan merupakan salah satu kriteria diagnostik dari gangguan cemas menyeluruh (Generalized Anxiety Disorder). Kecemasan yang secara signifikan mempengaruhi kehidupan sosial, pekerjaan, dan bagian penting lainnya merupakan gejala dari gangguan cemas sosial (Social Phobia). Depresi merupakan kondisi dimana seseorang merasa sedih, tidak berdaya, tidak bersemangat, tidak bergairah dalam kehidupannya. Gangguan depresi yang mempengaruhi kehidupan sosial, pekerjaan atau fungsi penting lainnya merupakan salah satu kriteria diagnosis gangguan depresi berat (Major Depressive Disorder) (Andy, 2015).

2. Analisis Bivariat

a. Hubungan Beban Kerja dengan Kondisi Psikologis Depresi

Berdasarkan penelitian ini kategori beban kerja menunjukkan bahwa nilai korelasi antara beban kerja dengan depresi perawat relawan yaitu $0,011<0,05$ artinya terdapat hubungan yang signifikan antara beban kerja dengan depresi. Faktor-faktor yang bisa menimbulkan depresi pada karyawan bermacam-macam, salah satunya beban kerja yang terlalu berat. Sejalan dengan pendapat dari dr. Andri SpKJ, FAPM dari Klinik Psikosomatik RS Omni Alam Sutera, mengatakan depresi muncul akibat adanya tekanan besar yang tidak mampu diadaptasi oleh orang tersebut. Dalam konteks pekerjaan, depresi bisa saja muncul akibat beban kerja yang terlalu banyak, hubungan yang tidak harmonis dengan atasan dan rekan kerja, atau hal-hal lain yang menyebabkan seseorang mengalami stres yang tidak bisa dikelola dengan baik. Dalam penelitian ini beban kerja didapatkan oleh semua orang ketika seseorang tersebut berkomitmen untuk bekerja, namun yang membedakan adalah seberapa besar beban kerja tersebut. Orang dengan depresi adalah orang yang tidak bisa lagi menangani stresor yang dimilikinya hingga akhirnya mengalami gejala depresi, gejala depresi ini timbul akibat berbagai macam hal yaitu salah satunya adalah dari beban kerja.

b. Hubungan Beban Kerja dengan Cemas

Nilai korelasi antara beban kerja dengan cemas perawat relawan yaitu $0,000<0,05$ artinya terdapat hubungan yang signifikan antara beban kerja dengan cemas. Hal ini didukung oleh pendapat IASC (2020) penyebab tenaga kesehatan mengalami kecemasan yakni tuntutan pekerjaan yang tinggi, termasuk waktu kerja yang lama jumlah pasien meningkat, semakin sulit mendapatkan dukungan sosial karena adanya stigma masyarakat 
terhadap petugas garis depan, alat perlindungan diri yang membatasi gerak, kurang informasi tentang paparan jangka panjang pada orang-orang yang terinfeksi, dan rasa takut petugas garis depan akan menularkan COVID-19 pada teman dan keluarga karena bidang pekerjaannya. Memberikan asuhan keperawatan pada pasien COVID-19 dapat berdampak negatif pada psikologis perawat. Dampak negatif psikologis yang dialami oleh perawat yakni kecemasan. Kecemasan adalah status emosional negatif yang dipersepsikan secara individual dan merupakan salah satu gangguan psikologis yang sering dialami oleh perawat. Pada masa pandemi seperti saat ini, jumlah pasien akan meningkat sehingga beban kerja akan meningkat, dan perawat akan merasa mudah lelah. Psikologi negatif lain yang dialami oleh perawat yakni rasa takut, insomnia dan gangguan mental lain.

c. Hubungan Beban Kerja dengan Stres

Nilai korelasi antara karakteristik beban kerja dengan stres perawat relawan yaitu $0,000<0,05$ artinya terdapat hubungan yang signifikan antara beban kerja dengan stres. Hal ini sejalan dengan penelitian sebelumnya oleh (Ihsan \& Rosyid, 2021) yang menyatakan ada hubungan yang siginifikan antara beban kerja dengan tingkat stres kerja perawat ruang isolasi di RSUD Kota Salatiga. Hasil menunjukkan bahwa jika beban kerja perawat rendah maka tingkat stres kerja perawat juga akan rendah, sebaliknya jika beban kerja perawat tinggi maka tingkat stres kerja juga tinggi. Adanya hubungan antara beban kerja dengan stres kerja dikarenakan banyaknya beban kerja atau tuntutan tugas yang diterima oleh pekerja. Beban kerja yang diterima seseorang harus sesuai atau seimbang terhadap kemampuan fisik kemampuan kognitif dan keterbatasan manusia yang menerima beban tersebut (Dwiyana, Sastria, \& Kassaming, 2021). Semakin tinggi beban kerja yang diberikan, semakin tinggi pula peluang terjadinya stres pada tenaga kerja. Dalam penelitian ini beban kerja memiliki keterkaitan yang cukup erat dengan kondisi stres seseorang, beban kerja perawat relawan COVID-19 tentu lebih berat dibanding perawat bukan relawan atau perawat yang tidak merawat pasien COVID-19, maka kondisi psikologis perawat relawan juga mengalami perubahan drastis seperti salah satunya membuat stressor yang meningkat ketika harus berhadapan atau melakukan perawatan terhadap pasien COVID-19 yang seperti diketahui bisa menularkan dan menimbulkan gejala yang berat. Ketika stressor meningkat dan tidak bisa ditangani dapat menimbulkan berbagai macam gangguan psikologis dan mental lain.

Terkait hubungan beban kerja dengan kondisi psikologis perawat relawan COVID-19 menurut peneliti reponden perawat relawan COVID-19 memiliki tanggung jawab yang sangat besar dalam melakukan perawatan klien. Pasien COVID-19 memiliki penanganan yang lebih khusus dan 
berbeda daripada pasien lain dari segi obat-obatan maupun perawatan. (Dwiyana et al., 2021). Perawat yang mengalami stres dan burnout memungkinkan mereka untuk tidak dapat menampilkan performa secara efektif dan efisien dikarenakan kemampuan fisik dan kognitif mereka menjadi berkurang yang kemungkinan dapat terjadi disebabkan karena ketidakseimbangan antara jumlah pasien dengan jumlah perawat yang bekerja di rumah sakit tersebut, sehingga perawat mendapatkan beban kerja yang lebih banyak dari pada kemampuan maksimal dari perawat tersebut sehingga perawat mengalami beban kerja mental dan menimbulkan tindakan tidak aman (Yudha Pratama Tarigan, 2021).

\section{Kesimpulan}

Berdasarkan data yang diperoleh dari hasil analisis yang dilakukan maka dapat ditarik kesimpulan bahwa hubungan beban kerja dengan kondisi psikologis perawat relawan COVID-19: (1.) Terdapat hubungan yang signifikan antara beban kerja dan depresi dengan p-value 0,011. (2.) Terdapat hubungan yang signifikan antara beban kerja dan cemas dengan p-value 0,000. (3.) Terdapat hubungan yang signifikan antara beban kerja dan stres dengan p-value 0,000 .

\section{BIBLIOGRAFI}

Andy, Andy. (2015). Perbedaan tingkat stres, kecemasan, dan depresi pada mahasiswa preklinik dan klinik Fakultas Kedokteran Universitas Tarumanagara. Universitas Tarumanagara.Google Scholar

Dwiyana, Novita, Sastria, Andi, \& Kassaming, Kassaming. (2021). Hubungan Stres Kerja Dan Beban Kerja Dengan Kepuasan Kerja Perawat Di Rumah Sakit Bhayangkara Makassar. JIKI Jurnal Ilmiah Kesehatan IQRA, 9(1), 22-30. Google Scholar

Cross-Sectional di Kota Pontianak. Jurnal Kesehatan Masyarakat Indonesia. Fakultas Ilmu Kesehatan. Universitas Muhammadiyah Pontianak. 15(2).

IASC. (2020). Catatan Tentang Aspek Kesehatan Jiwa Dan Psikososial Wabah COVID-19 (pp. $1-20)$.

Ihsan, Nabil Bakti, \& Rosyid, Fahrun Nur. (2021). Hubungan Beban Kerja Dengan Tingkat Stres Perawat Di Ruang Isolasi Covid-19 Rsud Kota Salatiga. Universitas Muhammadiyah Surakarta. Google Scholar

Hanggoro, AY., Suwarni, Linda., Selviana \& Mawardi. (2020). Dampak Psikologis Pandemi COVID-19 Pada Tenaga Kesehatan : A Study. Google Scholar

Putri, Alifia Fernanda. (2019). Pentingnya orang dewasa awal menyelesaikan tugas perkembangannya. SCHOULID: Indonesian Journal of School Counseling, 3(2), 35-40. Google Scholar

Rosyanti, Lilin, \& Hadi, Indriono. (2020). Dampak psikologis dalam memberikan perawatan dan layanan kesehatan pasien COVID-19 pada tenaga profesional kesehatan. Health Information: Jurnal Penelitian, 12(1), 107-130. Google Scholar 
Santoso, Teguh., Sari, DA \& Laely, AJ. (2020). Kondisi Psikologis Perawat yang Memberikan Asuhan Keperawatan Pada Pasien COVID-19: Tinjauan Narasi. Journal Of Clinical Medicine Medica Hospitalia. STIKES Guna Bangsa Yogyakarta. 7(1) pp 253-260. Google Scholar

Sabir, Nurfadillah, Arafat, Rosyidah, \& Yusuf, Saldy. (2021). Gambaran Faktor yang Mempengaruhi Kesehatan Mental Perawat pada Masa Pandemi Covid-19: Literatur Review. Jurnal Keperawatan, 13(1), 125-138. Google Scholar

Setyowati, Anggi, Chung, Min Huey, Yusuf, Ah, \& Haksama, Setya. (2020). Psychometric of the curiosity and exploration inventory-ii in Indonesia. Journal of Public Health Research, 9(3). Google Scholar

Tarigan, Sonia Amelia Pratiwi. (2021). Gambaran Persepsi Perawat Tentang Beban Kerja Selama Pandemi Covid-19 di Ruang Rawat Inap Isolasi Covid-19 Rumah Sakit Universitas Sumatera Utara. Google Scholar

Wijaya, Callistasia. (2020). Siapa Saja yang Paling Rentan Terkena dan Sakit Parah Akibat Virus Corona?. BBC News Indonesia. Diakses pada 20 November 2021, dari https://www.bbc.com/indonesia/indonesia-51411440. Google Scholar

Yunere, Falerisiska, \& Yaslina, Yaslina. (2020). Hubungan Stigma Dengan Kecemasan Perawat Dalam Menghadapi Pandemi Covid-19. Prosiding Seminar Kesehatan Perintis, 3(1), 1. Google Scholar

\section{Copyright holder:}

Firda Apriyanti, Yati Afiyanti, Syamsul Firdaus (2022)

\section{First publication right:}

Syntax Idea

This article is licensed under: 